\section{Institutional Pressures, Institutional Work and the Development of Universities' Entrepreneurial Turn}

\author{
Pressões Institucionais, Trabalho Institucional e o Desenvolvimento do \\ Direcionamento Empreendedor de Universidades
}

Juliana Marangoni Amarante ${ }^{\oplus}$ João Marcelo Crubellate ${ }^{2}$

\section{ABSTRACT}

Based on Institutional Theory, in this theoretical essay we aimed to create a model that could explain the development of the entrepreneurial turn of universities. As a result, we suggest the following theoretical proposition: universities' entrepreneurial turn is contingent on institutional work and may be understood as a result of a confluence of inward and outward forces that are shaped through a historical and recursive interplay between regulative, normative and cultural-cognitive pressures, conjointly derived from each actor of the Triple Helix, that is, the state, the industry - or society in a broader sense - and academia. Our main theoretical contributions consist of : (a) placing the universities' entrepreneurial turn at the epicenter of all the competing institutional pressures and logic when it comes to innovation creation; (b) characterizing the universities' entrepreneurial turn as a result of the recursive interplay between regulative, normative and cultural-cognitive pressures, conjointly derived from each actor of the Triple Helix; and (c) stressing the fundamental role of the institutional work performed by institutional entrepreneurs in the process of developing the universities' entrepreneurial turn.

Keywords: Theory; Triple Helix of Innovation; Entrepreneurial Universities; Institutional Entrepreneurs.

JEL Code: L26, B52, D4.

\footnotetext{
1 Universidade Estadual de Maringá, Departamento de Administração, Maringá, Paraná, Brazil.

2 Universidade Estadual de Maringá, Programa de Pós-Graduação em Administração, Maringá, Paraná, Brazil.
}

\section{RESUMO}

Com base na Teoria Institucional, neste ensaio teórico buscamos criar um modelo que explicasse o desenvolvimento do direcionamento empreendedor de universidades. Como resultado, sugerimos a seguinte proposição teórica: o direcionamento empreendedor de universidades é contingente ao trabalho institucional e pode ser entendido como o resultado de uma confluência de forças que atuam de dentro para fora e de fora para dentro, formadas por meio de uma interação histórica e recursiva entre pressões regulativas, normativas e culturaiscognitivas, derivadas conjuntamente de cada ator da tripla hélice, isto é, o estado, a indústria - ou a sociedade em um sentido mais amplo - e a academia. Nossas principais contribuições teóricas consistem em: (a) posicionar o direcionamento empreendedor de universidades no epicentro de todas as pressões e lógicas institucionais concorrentes quando se trata de criação de inovação; (b) caracterizar o direcionamento empreendedor de universidades como resultado da interação recursiva entre pressões regulativas, normativas e culturais-cognitivas, derivadas conjuntamente de cada ator da tripla hélice; e (c) enfatizar o papel fundamental do trabalho institucional realizado por empreendedores institucionais no processo de desenvolvimento do direcionamento empreendedor de universidades.

Palavras-chave: Teoria Institucional; Tripla Hélice da Inovação; Universidades Empreendedoras; Empreendedores Institucionais.

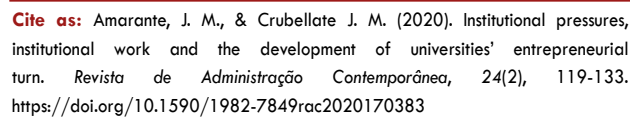
institutional work and the development of universities' entrepreneurial turn. Revista de Administração Contemporânea, 24(2), 119-133. https://doi.org/10.1590/1982-7849rac2020170383

Editor-in-chief: Wesley Mendes-Da-Silva Received: December 01, 2017 Last version received: August 11, 2019 Accepted: August 12, 2019

\# of invited reviewers until the decision

\begin{tabular}{|c|c|c|c|c|c|c|c|c|c|}
\hline & 1 & 2 & 3 & 4 & 5 & 6 & 7 & 8 & 9 \\
\hline $1^{\text {st }}$ round & (x) & (x) & (x) & (x) & (x) & (x) & (x) & (x) & $\stackrel{9}{2}$ \\
\hline $2^{\text {nd }}$ round & $\stackrel{8}{2}$ & & & & & & & & \\
\hline $3^{\text {rd }}$ round & $\stackrel{9}{=}$ & & & & & & & & \\
\hline
\end{tabular}




\section{INTRODUCTION}

Universities serve a multitude of purposes, guided by different interests from different actors (Pache \& Santos, 2010), as they possess a key role in the development of society, not only in its cultural context, but also socially and economically (United Nations Educational, Scientific and Cultural Organization [UNESCO], 1998) creating, transmitting and disseminating knowledge. "Far from being ivory towers, today universities have come to be regarded as important engines of economic growth and social change" (Vorley, 2015, p. xxiv).

Teaching, research and the wide range of activities that represent universities' Third Mission, are closely connected to each other, with blurred boundaries (Krause, 2009), forming a continuous cycle in which one mission is at the same time the foundation and the result of the other missions. The need to discover leads to the mission of researching. The need to learn what is already discovered leads to the mission of teaching. And the need to engage in meeting society's needs leads to the third mission, which involves the development of an entrepreneurial character, as demonstrated by many studies (Dias \& Silveira Porto, 2013; Rosa \& Frega, 2017; Almeida et al., 2016; Audy, 2017; Mello \& Sepúlveda, 2017; Rodrigues \& Gava, 2016).

As certain third mission activities unfold, some universities take what is called an entrepreneurial turn (Goldstein, 2010), that can be roughly understood as a deliberate change in a university's course of actions expressed by a strong commitment to an entrepreneurial posture and reflected not only by the commercialization of inventions, but mainly by a whole supportive structure to allow it to happen easily.

Innovation has become a key topic in organizational studies in recent times (Schmidt, Balestrin, Engelman, \& Bohnenberger, 2016; Agune \& Carlos, 2017; Plonski, 2017; Arbix \& Miranda, 2017). According to Etzkowitz (2008), in knowledge-based societies, innovation arises from Triple Helix relations, that is, from the interaction between university, industry and government, with a more prominent role of universities, given their research potential. Thus, we can state that central to the creation of innovation is the universities' entrepreneurial turn.

However, universities do not just turn in a more entrepreneurial direction out of nowhere. This turn is made as a result of a complex set of pressures, that can be synthesized as regulative, normative and culturalcognitive (Scott, 2014), conjointly derived from each one of the elements of the helix, that is, the state, the industry (society, in a broader sense), and academia itself. The most important point is that this is not a oneway process, but instead, one that is two-way. In other words, as the universities take a more entrepreneurial turn, their behavior also influences the institutional environment, creating new pressures, new conditions and standards, allowing that continuous cycle to occur, since "a field constructs a social universe in which all participants are at once producers and consumers, caught in a complex web of social, political and cultural relations that they themselves have woven and continue to weave" (Ferguson, 1998, p. 598).

In this sense, the role of institutional work performed by institutional entrepreneurs emerges. While when speaking of institutional pressures and organizational responses, we often rely on macro analysis, institutional work is conducted by individuals and so, it is fundamental to conduct research that focuses on "how institutions operate through the influence and agency of individuals" (Suddaby, 2010, p. 17). Logically, an institutional change, as for example the universities' entrepreneurial turn, would not result from only one institutional entrepreneur, nor an individual or a single organization/university, but rather, from collective institutional work performed by several actors who contribute individually with their own skills (Greenwood \& Suddaby, 2006). Therefore, it is useful to look at individual actions to understand institutional changes achieved collectively.

Following what has been presented, with this study we aim to contribute to the advancement of two research fields: the Institutional Theory field and the Triple Helix of innovation field. We intend to accomplish this by connecting both, providing insights on how the universities' entrepreneurial turn evolves as a result of institutional processes and most importantly, emphasizing the institutional work performed by institutional entrepreneurs in this process.

As stated by Suddaby (2010), there is an absence of individual analysis in institutional research. According to the author

Institutional work, of course, is conducted by individuals and it is somewhat surprising to me how individuals often disappear from institutional research ... if we take seriously the notion that institutions are powerful instruments of cognition, there must be some opportunity in conducting research on how institutional logics are understood and influence at the individual level of analysis ... Yet I am surprised at how little effort has been expended by institutional researchers to understand how institutions operate through the influence and agency of individuals. This is, I think, an area of high opportunity for future inquiry. (p. 17)

In this sense, if we consider the relevance to the Institutional Theory field, our paper is particularly important because our proposed model may help researchers shed light on how individual actions, that 
promote entrepreneurship within the three spheres of the Triple Helix, shape, and are shaped by, the institutional environment.

In addition, our model also contributes to the Triple Helix field of studies, providing a framework that can be used by researchers who want to conduct comparative or even single case studies regarding the development of any university's entrepreneurial turn. Our model stresses the pressures that need to be taken into account as well as the strong intertwined connections between them.

Before moving on to the core argumentation of this essay, some fundamental theoretical concepts will be presented in the next section. Thereafter, the following section will be dedicated to the argumentation of our thesis, that is, to comprehend the entrepreneurial turn through the convergence between these two theoretical streams, the Triple Helix and Institutional Theory. Lastly, concluding remarks will be drawn.

\section{FUNDAMENTAL CONCEPTS BEFORE CORE ARGUMENTATION}

The ways that universities relate and contribute to the environment in which they operate can be summarized in three main missions that are comprised of diverse activities. The first mission is teaching, which serves both individuals, by providing a learning experience that will influence their lives as a whole, and organizations, by providing a prepared workforce.

The second mission is research, which is connected in the short run to the impetus for discovery, and in the long run the basis for teaching. According to Brew (2009) research can serve a multitude of interests, most of the times conflicting, arising from the government, the industry, the media and the academics themselves.

The third mission embraces a wide range of activities that represent universities' commitment to engage in attending society's needs in more direct ways such as: extension courses; services to benefit the local community, and informal or formal relationships with industries. "... concerned with the generation, use, application and exploitation of knowledge and other university capabilities outside academic environments. In other words, the Third Stream is about the interactions between universities and the rest of society" (Mollas-Gallart, Salter, Patel, Scott, \& Duran, 2002, pp. iii-iv).

Given the great impact of innovation, as a nonmaterial resource, on regional competitiveness and consequently on its economic development (Capello, Olechnicka \& Gorzelak, 2013), the role of universities in this context is overt. It is important to highlight that as universities are not expected to literally produce goods as would a factory, some of the discoveries that emerge from academic research demand third-party involvement to achieve their full potential and benefit the general public. This is when the universities' third mission acquires an entrepreneurial characteristic.

The third mission encompasses knowledge transfer from universities to the industry; the capitalization of knowledge by its ownership and commercial use; the creation of contracts both with industry and public spheres; and the academic's active participation in policy making, both directly or indirectly through advisory boards (Schoen et al., 2006).

However, being entrepreneurial does not only have to do with commercializing inventions, it also demands a whole supportive structure to allow it to happen properly. Therefore, some universities have taken an 'entrepreneurial turn' that, according to Goldstein (2010), includes

(1) the active involvement of universitiesas institutions - in the development and commercialization of technology stemming from university-based research; and; (2) changing the internal regulations, rewards and incentives, norms of behavior, and governance of universities to remove barriers to individual faculty, other researchers, and research centers/ institutes engaging in behavior that leads to the commercialization of university-generated knowledge (p. 84).

Connected with the concept of the universities' entrepreneurial turn is the concept of what Vorley and Nelles (2008) refer to as Entrepreneurial Architecture, which can be understood as internal factors that, in aggregate, shape universities' entrepreneurial agendas. This architecture involves structures, such as technology transfer offices, incubators and technology parks; systems that allow connections between the administration and the structure; leadership of key people within universities that influences others' behavior, such as the Star Scientists, or department heads; strategies refer to the institutional goals and policies related to the universities' third mission, and; culture that refers to the norms and attitudes towards entrepreneurship both institutionally, departmentally and individually.

In knowledge-based societies, innovation arises from Triple Helix relations, that is, from the interaction between university, industry and the State (Etzkowitz, 2008). Figure 1 shows a synthetic representation of Triple Helix Systems. 


\begin{tabular}{|c|c|c|}
\hline Components & Relationships & Functions \\
\hline $\begin{array}{l}\text { University - Industry- } \\
\text { Govemment institutional } \\
\text { spheres: } \\
\text { - R\&D and non-R\&D } \\
\text { innovators } \\
\text { - Single sphere and multi } \\
\text { sphere (hybrid) institutions } \\
\text { Individual innovators and } \\
\text { institutional innovators }\end{array}$ & 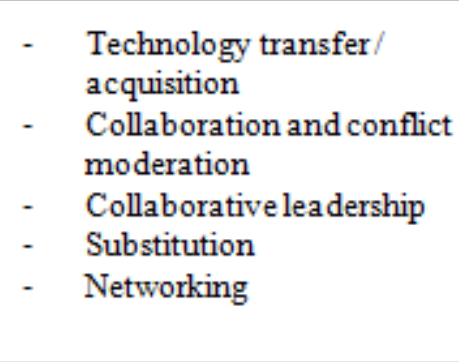 & $\begin{array}{l}\text { Main function: generation, } \\
\text { diffusion and use of } \\
\text { knowledge and innovation } \\
\text { Realized through } \\
\text { articulation of the: } \\
\text { - Knowledge space } \\
\text { - Innovation space } \\
\text { - Consensus space }\end{array}$ \\
\hline
\end{tabular}

Figure 1. Components, Relationships and Functions of Triple Helix Systems.

Source: Adapted from Ranga, M., \& Etzkowitz, H. (2013). Triple helix systems: An analytical framework for innovation policy and practice in the knowledge society (p. 241). Industry \& Higher Education, 27(3), 237-262. https://doi.org/10.5367/ihe.2013.0165.

As we can see, the main function of Triple Helix systems consists of the articulation of the spaces of knowledge, innovation and consensus aiming at the generation, diffusion and use of knowledge and innovation.

For this to happen, multiple diverse components of the Triple Helix, that is, individual or collective actors pertaining to one or more spheres, have to engage in relationships such as technology transfer, networking, collaborative leadership, and other practices that lead to increasing interactions between the spheres, allowing the formation of a Stem Cell Space, as it is shown in Figure 2, which will then differentiate and form spaces of knowledge, innovation and consensus.
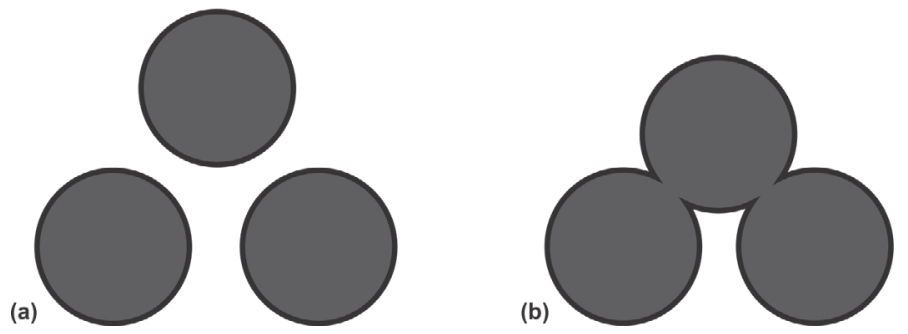

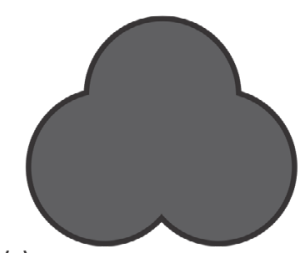

(c)

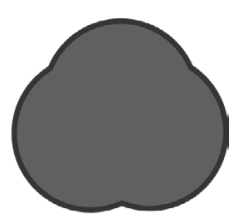

(d)

Figure 2. Triple Helix Interactions and the Formation of a Space: (a) institutional spheres apart - a laissez-faire regime; (b) institutional spheres getting closer together and starting to interact; (c) institutional spheres increasingly overlapping; and (d) institutional spheres overlapping in a balanced regime - formation of a 'stem cell space'.

Source: Adapted from Ranga, M., \& Etzkowitz, H. (2013). Triple helix systems: An analytical framework for innovation policy and practice in the knowledge society. Industry \& Higher Education, 27(3), 237-262. https://doi.org/10.5367/ihe.2013.0165

The formation of the spaces depends on the mobilization of specific components and relationships and is contingent on contextual factors such as local needs, resources and most importantly, it depends on the motivation of Triple Helix actors to work together, aiming to achieve common goals. According to Ranga and Etzkowitz (2013)

The knowledge space encompasses the competencies of knowledge generation, diffusion and use of the Triple Helix components. The construction of this space is an essential step in the transition to a knowledge society and has the purpose of creating and developing knowledge resources in order to strengthen the local, regional and national knowledge base, to avoid fragmentation and to reduce the duplication of research efforts ... The innovation space consists in particular of the competencies of the 'multi-sphere' (hybrid) organizations and entrepreneurial individuals and institutions ... Its ultimate purpose is the development of local innovative firms, in parallel with the attraction of talent and innovative firms from elsewhere, the creation and development of intellectual and entrepreneurial potential, and competitive advantage for the region and the country ... The consensus space is the set of competences that bring together the Triple Helix system components to engage in 'blue-sky' thinking, discuss and evaluate proposals for advancement towards a knowledge-based regime. (p. 247) 
Given the contextual nature of universities' third stream activities, institutional theory is regarded as a particularly appropriate approach to understand the historical dynamics that shape the institutional environment in which the universities' entrepreneurial turn is embedded. As pointed out by Hoffman (1997), "In setting strategy and structure, firms may choose action from a repertoire of possible options. But the range of that repertoire is bound by the rules, norms and beliefs of the organizational field" (p. 148).

Institutional theory has proven that the explanatory capacity within organizational studies is far from being exhausted, as stated by Scott in a recent interview (Scott, 2016). This theoretical framework continues to catch the attention of researchers all over the world, including in Brazil, where this framework has been seen in recent years in many publications of institutional theory, such as for example, Rossoni, Guarido Filho and Coraiola (2013); Popadiuk, Rivera and Bataglia (2014); Rossoni (2016); de Mello (2017) and Machado, Sartori and Crubellate (2017).

The use of Institutional Theory enriches the possibilities for interpretation of why actors, whether individual or collective actors, behave the way they do. Their actions can be comprehended as a result of a complex set of institutional pressures, which can be synthesized as regulative, normative and culturalcognitive (Scott, 2014). Our proposed model, presented ahead in this paper, congregates institutional theory and the Triple Helix theory, because we are mostly concerned about how the processes unfold rather than what the results are.

"Institutions comprise regulative, normative and cultural-cognitive elements that, together with associated activities and resources, provides stability and meaning to social life" (Scott, 2014, p. 56). Starting with this broad definition of institutions, we can think of the countless processes that affect each individual and organization, at such a deep level that they lead to not only the understanding of social reality, but also its continuous construction.

The regulative pressures inform actors of the regulations they are subject to. The normative pressures inform them what the goals are and how they should pursue them. And, finally, the culturalcognitive pressures define how actors perceive all the stimuli, which is a very fundamental issue. Having all these institutional pressures affecting their daily choices, behaviors and actions, actors contribute to the perpetuation of institutions. Paradoxically, this is exactly what allows institutional change, because actors are simultaneously embedded in multiple fields and so, subject to many institutional pressures and end up transposing logic of action from one institutional context to another (Boxenbaum \& Battilana, 2005). Thus, social actors are both products and producers of institutional logic (Bjerregaard \& Jonasson, 2014), given that their responses to institutional pressures keep feeding the institutional environment over time with a complex recursive relational dynamic.

This dynamic between structure and agents is what allows institutional innovations, but it is important to highlight that "the practices which might lead to institutional innovations are themselves institutionally embedded and so, rely on sets of resources and skills that are specific to the field or fields in which they occur" (Lawrence \& Suddaby, 2006, p. 220).

Tolbert, David and Sine (2011) complement arguing that on the one hand, the way entrepreneurs perceive opportunities as well as the way they explore them are shaped by institutions. And on the other hand, entrepreneurs are themselves crucial to the processes that institutionalize new practices, forms and structures, thus shaping the institutional world.

DiMaggio (1988) introduced the notion of institutional entrepreneurship, which expresses the agency of institutional entrepreneurs as they arrange resources in order to create and empower institutions, according to their interests.

This concept is not separate from the traditional notion of commercial entrepreneurship (Phillips \& Tracey, 2007). Institutional entrepreneurs can also be defined as "change agents who, whether or not they initially intended to change their institutional environment, initiate, and actively participate in the implementation of changes that diverge from existing institutions" (Battilana, Leca \& Boxenbaum, 2009, p. 70).

As we can see, institutional entrepreneurship emphasizes the idea of the recursive interplay between institutional pressures and responses, admitting that today's actions may become tomorrow's pressures, to put in a very simple perspective. It also helps to understand the enduring, yet by no means permanent nor unchangeable, nature of institutional pressures, which are products of human construction and thus, subject to human agency.

The concept of institutional work, therefore, can be understood as "the sets of practices through which individual and collective actors create, maintain and disrupt the institutions of organizational fields" (Lawrence \& Suddaby, 2006, p. 220).

Hence, in order to understand the dynamics that explain the universities' entrepreneurial turn, we need to look at the recursive interplay between these universities and their institutional environments, mediated by individual and collective agents, because this historical dynamic is what shapes both individual and collective pressures and responses, in accordance to points made by Padgett and Powell (2012) and also Scott (2014) : "In the short run, actors create relations; in the long run, relations create actors" (Padgett \& Powell, 2012, p. 2). And "In the short run, actors create 
and modify meanings; in the long run, meanings create actors, both organizational and individual identities" (Scott, 2014, pp. 223).

The purpose of this section was to lay the groundwork for our core argumentation that comes in the next section, that is, to explain the entrepreneurial turn of universities through the convergence between the Triple Helix of Innovation and Institutional Theory. Therefore, we have presented and discussed some fundamental concepts that needed to be fully comprehended in order to allow us to build our proposed model. Hence, three main subjects were addressed: (a) the universities' third mission and its relation with the idea of an entrepreneurial turn, supported by an entrepreneurial architecture; (b) the Triple Helix of Innovation and; (c) the Institutional Theory as an appropriate approach to comprehend the development of universities' entrepreneurial turn.

\section{THE CONVERGENCE BETWEEN THE TRIPLE HELIX AND INSTITUTIONAL THEORY}

We start our argumentation with Figure 3, which is a representation of the relations between some fundamental variables of our model.
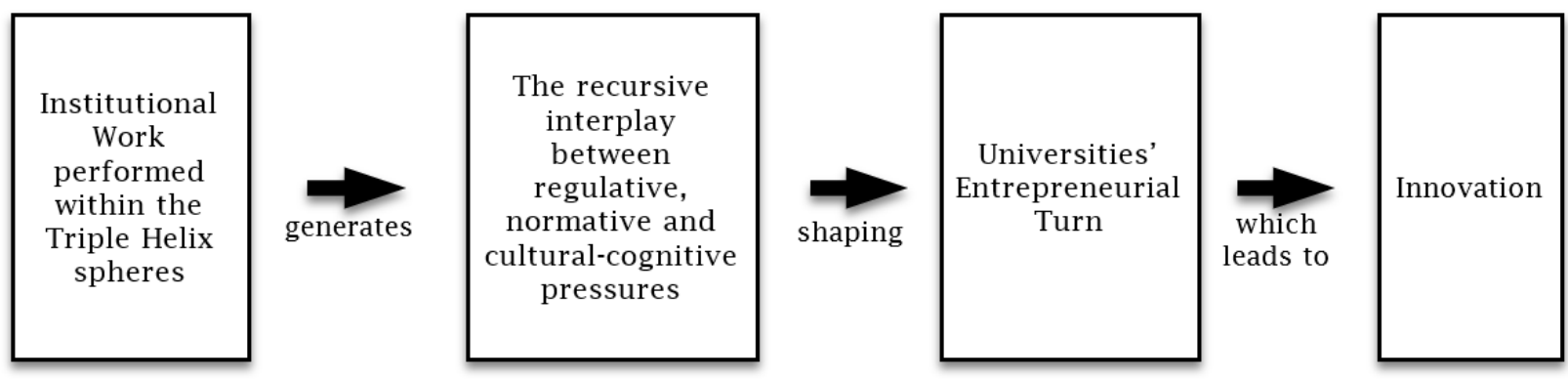

Figure 3. Relations between some Fundamental Variables of our Model.

Source: The authors.

There have been many recent research initiatives that deal with the innovation issue through the lens of the Triple Helix (Leydesdorff \& Park, 2014; Havas, 2015; Luengo \& Obeso, 2013; Petersen, Rotolo, \& Leydesdorff, 2016; Pinto, 2017; Etzkowitz \& Zhou, 2017), and even others that combine this theoretical stream with institutional theory, such as those presented in the book entitled The entrepreneurial university: context and institutional change, edited by Foss and Gibson (2015b), and others like, Machado, Sartori and Crubellate (2017) and Gibson and Foss (2017).

Our overall theoretical proposition is: universities' entrepreneurial turn is contingent on institutional work and may be understood as a result of a confluence of inward and outward forces that are shaped through a historical and recursive interplay between regulative, normative and cultural-cognitive pressures, conjointly derived from each actor of the Triple Helix, that is, the state, the industry - or society in a broader sense - and academia.

Our main theoretical contributions, or the novelty of our thesis, consist of: (a) placing the universities' entrepreneurial turn at the epicenter of all the competing institutional pressures and logic when it comes to innovation creation; (b) characterizing the universities' entrepreneurial turn as a result of the recursive interplay between regulative, normative and cultural-cognitive pressures, conjointly derived from each actor of the Triple Helix; and (c) stressing the fundamental role of the institutional work performed by institutional entrepreneurs in the process of developing the universities' entrepreneurial turn.

With the intent of making our thesis clearer, we will describe each of these three theoretical contributions in more details in the following paragraphs.

When we claim that the entrepreneurial turn is at the epicenter of all the competing pressures and logic when it comes to innovation creation, we base our argument on the following ideas. In knowledge based societies, what is considered an innovation truly depends on research in order to emerge. We can think of research as being the real locus of innovation, which is especially true if we consider technological innovation. Research, in turn, depends on universities to exist, both directly and indirectly. Although one may claim that there are research centers outside of universities, we need to remember that the human capital, the entrepreneur scientists, involved in creating innovations in these centers, are fruits of universities' efforts, most of which at one point decided to take an 
entrepreneurial turn and promote entrepreneurial thinking among its faculty, researchers and students.

Considering that in knowledge-based societies innovation arises from Triple Helix relations, demanding a more prominent role of universities (Etzkowitz, 2008), it is appropriate to think about the universities' entrepreneurial turn (Goldstein, 2010) as a decisive direction they take, without which the promotion of innovation would not be something systematized and thus, would be rarer and would happen at a slower pace.

Therefore it seems suitable to consider the entrepreneurial turn as the ultimate means that leads to the promotion of innovation. And as it is expected, its responsibility does not come out of a vacuum, but it is rather a result of inward and outward forces, that can be understood as institutional pressures and organizational responses to the environment, that are shaped through a historical recursive interplay between regulative, normative and cultural-cognitive forces conjointly derived from each actor of the Triple Helix.

This drives us to a more refined level of detail in our thesis' second assertion, that consists of characterizing the universities' entrepreneurial turn as a result of the recursive interplay between regulative, normative and cultural-cognitive pressures, conjointly derived from each actor of the Triple Helix.

As pointed out by Foss and Gibson (2015a), the context in which the university is embedded has a profound impact on how the entrepreneurial architecture will be built, in other words, the speed and depth of development of each dimension, namely the structures, strategies, systems, leadership and culture. And, according to our thesis, the university's entrepreneurial architecture also impacts its context simultaneously.

Government regulations both restrict and enable individual and organizational behaviors and the emergence of a regulation is not a synonym for a top-down process. According to Scott (2014) "Individuals craft laws and rules that they believe will advance their interests, and individuals conform to laws and rules because they seek the attendant rewards or wish to avoid sanctions" (p 62). Thus, the way through which laws or other kinds of regulations emerge reflects political processes which involve interests deriving from diverse groups of interests in society.

This bottom-up characteristic of the lawmaking process is quite clear if we consider the pressures that interest groups exert on the regulative sphere through lobby. Their political power may change the course of legislation. This kind of practice, however, as noted by Schattsschneider (1975) is predominantly performed by businesses, whose power "challenges the supremacy of government" (p. 116). In other words, the power to interfere in the regulative process will be greater in the case of organizations, or groups of organizations that have a strong political articulation power, and lower in the case of other types of societal pressures.

Regarding the third mission of universities, most regulations have to do with the ways through which they can commercially engage in research. If we continue to use the USA as an example when it comes to this issue, the Bayh-Dole Act is regarded as being one of the major changes that occurred in the country. According to Loise and Stevens (2010) "Bayh-Dole gave ownership of inventions back to the universities that created them and gave universities the freedom to negotiate whatever license terms would best encourage development of the technology" (p.1).

Powerful universities such as Stanford, University of California and Harvard lobbied for the passage of this bill (Mowery, 2005). This demonstrates that even regulative pressures are not simply given, but rather a result of a construct that involves both government and groups of interests that exert pressure over the policy making process.

It is important to make a final remark about the nature of regulative pressures. As it was mentioned before, government regulations at the same time restrict and enable individual and organizational behavior. Thus, state pressures must be understood in a broader way that also embraces budgetary decisions that direct funds to university laboratories as part of governmental strategic decisions. A well-known example of this is the US government's investments during wartime that "...spurred the growth of new industries and regions by channeling resources to university labs to develop war-related technologies" (Saxenian, 1994, p. 11).

As we can see, the state plays a fundamental role in the development of the universities' entrepreneurial turn, but it is also dependent on another kind of pressure that emerges from industry, or society in a broader sense. This kind of pressure sets the goals and the ways through which actors should pursue them.

The normative rules are responsible for the prescriptive, obligatory and evaluative character of social life. Normative systems encompass values and norms. Values refer to "conceptions of the preferred or the desirable together with the construction of standards to which existing structures or behaviors can be compared and assessed. Norms specify how things should be done; they define legitimate means to pursue valued ends" (Scott, 2014, p. 64). 
The notion of role derives from normative systems, as some values and norms are applicable to some specific actors (Scott, 2014). If we take universities as an example, it is possible to see that their role has changed over time. "Far from being ivory towers, today universities have come to be regarded as important engines of economic growth and social change" (Vorley, 2015, xxiv). Nowadays, society relies more and more on universities to generate innovation capable of transforming the reality of nearby communities and even the world as a whole.

If some universities' behaviors were considered unprecedented when they started taking an entrepreneurial turn, the reality for these universities nowadays is quite different, that is, the expectation for them to act entrepreneurially has been set. The shift in what their roles are represents changes in society's values and norms, which are in turn, influenced by diverse institutional pressures, among which some universities' entrepreneurial turn can be highlighted. In other words, the entrepreneurial experience of some leading universities has contributed to changes in the way society perceives the universities' role. This helps demonstrate how the recursive interplay between the institutional pressures is in charge of shaping these pressures themselves.

Cultural - cognitive pressures are also a determinant when it comes to the development of the entrepreneurial turn of universities. As it was presented previously, the cultural-cognitive aspect of social life determines how actors perceive all institutional stimuli. "Mediating between the external world of stimuli and the response of the individual organism is a collection of internalized symbolic representations of the world ... Internal interpretive processes are shaped by external cultural frameworks" (Scott, 2014, p. 67).

Usual indicators of the cultural-cognitive pillar of institutions are common beliefs, shared logic of action, and isomorphism, while the basis of compliance is taken-for-grantedness and shared understanding. Although human cognition is an internal interpretive process, its foundations rest mostly on external cultural frameworks, and so, it constitutes an institutional pressure, evidencing its origin through recursive relational dynamics (Scott, 2014).

DiMaggio and Powell (1983) argue that when organizational fields are in the beginning, still structuring themselves, they present greater diversity, but as they are established and become more elaborate, differentiation gives way to homogenization. This is because it is critical to the success and survival of organizations embedded in highly elaborate institutional settings that they become environmentally isomorphic. For DiMaggio and Powell (1983), isomorphism is "...the concept that best captures the process of homogenization..." (p.149) and according to them, there are two types of isomorphism: the competitive and institutional. Competitive isomorphism shapes organizations taking into account the technical environment they are part of. Institutional isomorphism, in turn, results from the organizational adequacy to the existing pressures in the institutional environment, that is, what provides legitimacy in the context in which the organizations are embedded (DiMaggio \& Powell, 1983; Machado-Da-Silva \& Fonseca, 1996).

Practices that were once considered unconventional in their institutional contexts, as time goes by, become legitimate and institutionalized, shaping their own institutional environment. The entrepreneurial experience of some leading universities has contributed to changes in the way society perceives the universities' role. The case of Stanford University demonstrates this movement. The development of its entrepreneurial turn began to influence other universities to act in a similar way, adapting their structures and strategies to be more entrepreneurial as well.

According to Hofstede (1991) culture functions as the "software of the mind" (p. 4), which means it provides patterns for acting and mainly feeling and thinking. As we can see, it brings meaning to human action. Related to this idea, Berger and Kellner (1981) emphasize the nature of human institutions.

Every human institution is, as it were, a sedimentation of meanings, or, to vary the image, a crystallization of meanings in objective forms. As meanings become objectivated, institutionalized, in this manner, they become common reference points for the meaningful actions of countless individuals, even from one generation to the next. (p. 31)

As we can see, the cultural-cognitive pressures are inherently resultant from a recursive interplay between the world and the actor. Following what these authors claim, cultural frames affect cognition and, therefore, organizational decisions. If we think of institutional entrepreneurs such as Frederic Terman, considered by many as the father of Silicon Valley due to his remarkable work at Stanford University (Gillmor, 2004), we can assume that these individuals, who play fundamental roles in leading great institutional changes, somehow translate the world of institutional stimuli under their own internalized symbolic representations of the world and then share the meanings, through actual leadership, to the point that these meanings become objectified and institutionalized, guiding other people's actions throughout time. 
This leads us to our final theoretical contribution, which is stressing the fundamental role of the institutional work performed by institutional entrepreneurs in the process of developing the universities' entrepreneurial turn.

Universities constitute one of the best examples of complex organizations and as a consequence, face inherent conflictual situations motivated by its loosely coupled character (Weick, 1976) and also by the lack of control and the emergence of autonomous decisions by its members, that allows them to be regarded as organized anarchies (Cohen, March, \& Olsen, 1972). As a consequence, universities' strategies on their entrepreneurial turn tend to be not consensual, but rather negotiated, bargained and resultant from internal and external political processes.

According to Lawrence and Suddaby (2006), looking at institutional work helps analyze the interactive elements and moments of institutions' production, and thus, different forms of institutional work related to each goal can be identified, that is, creating, maintaining and disrupting institutions. Regarding the creation of institutions, in summary, the efforts are dedicated to mobilize political and regulatory support; construct rule systems and structures; construct identities; change associations between practices and moral and cultural foundations; facilitate the adoption of practices by associating them with taken-for-granted practices; and educating actors according to the new institution in order to support it. When it comes to maintaining institutions, the institutional work involved is dedicated to ensure adherence to rule systems, and at the same time, guaranteeing the reproduction of existing norms and belief systems. Finally, the forms of work applied for the disruption of institutions, has to do with "attacking or undermining the mechanisms that lead members to comply with institutions" (Lawrence \& Suddaby, 2006, p. 235).

Returning to the concept of the Triple Helix, Ranga and Etzkowitz (2013) also acknowledge the relevant role of individual innovators in the processes involved in generating innovation through the Triple Helix. They describe the work of entrepreneurial scientists and innovation organizers. The former balance academic and business interests exploring both theoretical and practical opportunities of knowledge. The latter is a person

who typically occupies a key institutional position, enunciates a vision for knowledgebased development and has sufficient respect and authority to exercise convening power to bring the leadership of the institutional spheres together ... Innovation organizers can come from any institutional sphere. They coordinate a mix of top-down and bottom-up processes and innovation stakeholders from different organizational backgrounds and perspectives, who come together to build a platform for new ideas, promote economic and social development and ensure agreement and support for their realization. A process of 'cross-institutional entrepreneurship' spanning the Triple Helix spheres is thus initiated for improving the conditions for knowledge-based development (Ranga \& Etzkowitz, 2013, pp. 242-243).

Therefore, the role of institutional work performed by institutional entrepreneurs becomes evident not only when it comes to the development of universities' entrepreneurial turn, but also to the development of Triple Helix relations as a whole.

\section{Our model}

Based on what has been shown, the development of universities' entrepreneurial turn can be fruitfully explained through a perspective that combines Institutional Pressures and Institutional Work, with the Triple Helix of Innovation as the backdrop.

Our theoretical overall proposition, as already presented, is derived from Etzkowitz (2008) balanced Triple Helix model (see Figure 2, item d previously presented in this paper), where the intersection of the three spheres makes it possible for trilateral networks and hybrid organizations to exist.

However, when it comes to innovation creation in the knowledge society, we believe that the boundaries between the three spheres, that is, the dividing lines between state, academia and industry/ society, as well as the three configurations of institutional pressures, that is, regulative, normative and cultural cognitive, can not be clearly observable and distinguishable, when the three spheres start to overlap. Thus, our model is better demonstrated through a color gamut, due to the blurred boundaries that this Figure represents.

In a color gamut there are RGB - red, green and blue interactions that create a whole new set of colors according to the intensity of the participation of each RGB color, as can be seen in Figure 4.

Both images shown in Figure 4 are the same. The difference is that the one on the left is a simplification of the one on the right side, which is more complex and accurate according to the reality. The interactions in the image to the left show clear boundaries between the three colors. While in the image to the right, the boundaries are blurred and it is much more difficult to identify the exact point where one color begins and where it ends. 


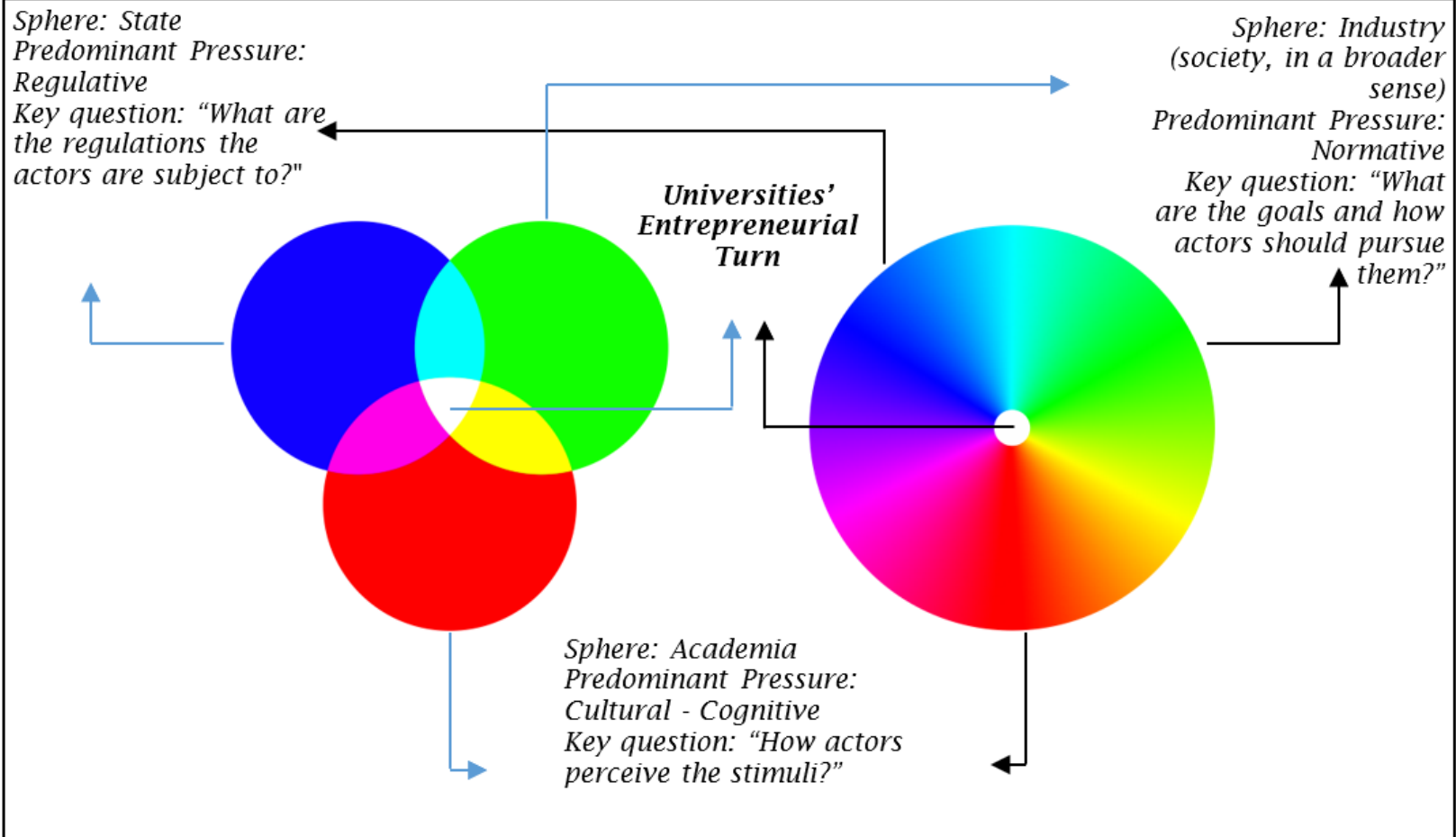

Figure 4. Simplified vs. Complex Representation of Institutional Pressures and the Three Spheres of the Triple Helix of Innovation Shaping Universities' Entrepreneurial Turn

Source: The authors.

The same happens when institutional entrepreneurs from the state, the industry/society and academia work institutionally, both individually and collectively and favor innovation creation, many times promoting the emergence of hybrid innovators. We can mention, for instance, meta-organizations that support the development of entrepreneurship among and across the three spheres of the helix. According to Gulati, Puranam and Tushman (2012)

Meta-organizations comprise networks of firms or individuals not bound by authority based on employment relationships but characterized by a system-level goal. As in a traditional organization, the existence of a system level goal does not imply that the constituent agents share it; profit maximization may be the goal of the business firm but not necessarily of all its employees. Thus, even in a meta-organization, each agent has its own motivations, incentives, and cognitions, but unlike in a traditional business firm, they are not linked via a framework of formal authority associated with employment contracts (p. 577).

In Brazil, a relevant example of this kind of metaorganization is FORTEC - Associação Fórum Nacional de Gestores de Inovação e Transferência de Tecnologia. It is a non-profit civil association formed by individuals and organizational bodies, both public and private, that share mutual interests regarding the production, promotion and development of innovation in the country. In short, this meta-organization aims to create and develop a well-structured innovative environment, marked by cooperation among actors from different affiliations (Associação Fórum Nacional de Gestores de Inovação e Transferência de Tecnologia [FORTEC], 2015).

On a larger scale, AUTM, based in The United States of America and formerly called the Association of University Technology Managers, is another example of a meta-organization. According to its own webpage, it has 3000 members who work in 800 institutions throughout 65 countries. $67 \%$ of them are in the academic sector, $15 \%$ of them are attorneys and $5 \%$ of the members are in industry. "AUTM is the largest self-funded, nongovernmental, non-profit leader in efforts to educate, promote and inspire technology transfer professionals, throughout their careers, to support the development of academic research that changes the world" (AUTM, 2019).

Besides promoting international cooperation, and specific training for technology transfer professionals, the AUTM Innovation Marketplace is its most noteworthy functionality. It provides a platform that connects academic inventions and industry needs (AUTM, 2019).

Returning to the graphic representation of our thesis, it also better illustrates the recursive interplay between the institutional pressures that shape 
universities' entrepreneurial turn. More than just being in contact, the institutional pressures simultaneously transform and shape one another, in a continuous process resulting from the institutional work performed by institutional entrepreneurs.

And finally, this Figure also sheds light on the central position of universities' entrepreneurial turn in the process of creating innovations. Being at the epicenter of all institutional pressures coming from a multitude of actors of the three spheres, highlights the contingent nature of universities' entrepreneurial turn and, above all, reinforces the absolute relevance of the institutional work performed by institutional entrepreneurs in shaping its development.

\section{CONCLUDING REMARKS}

In this essay we have suggested the following theoretical proposition: universities' entrepreneurial turn is contingent on institutional work and may be understood as a result of a confluence of inward and outward forces that are shaped through a historical and recursive interplay between regulative, normative and cultural-cognitive pressures, conjointly derived from each actor of the Triple Helix, that is, the state, the industry - or society in a broader sense - and the academia.

Our main theoretical contributions consist of: (a) placing the universities' entrepreneurial turn at the epicenter of all the competing institutional pressures and logic when it comes to innovation creation; (b) characterizing the universities' entrepreneurial turn as a result of the recursive interplay between regulative, normative and cultural-cognitive pressures, conjointly derived from each actor of the Triple Helix; and (c) stressing the fundamental role of the institutional work performed by institutional entrepreneurs in the process of developing the universities' entrepreneurial turn.

Based on what has been argued throughout this essay, it is possible to draw some concluding remarks. The first, constitutes a practical implication that is especially relevant to developing countries, like Brazil, that seek more competitiveness in technological markets along with a more prominent role of universities in development of the regions where they are embedded. Our thesis suggests that the way in which universities develop entrepreneurially does not depend solely on their will. Actually, universities' entrepreneurial turn is a result of a complex set of institutional processes that is unique to each university across the globe. For this reason, trying to replicate successful models of entrepreneurial universities may prove to be useless due to the contingent characteristic of the institutional environments in which they operate. The three spheres of the helix must work together to promote innovation.
The Brazilian economy is not yet knowledgebased. In fact, the country's economy strongly relies on commodities. However, there is a growing shared understanding among scientists that the Brazilian universities cannot be looked at separately from the rest of the economic world. Nowadays, science is closer to the market than it was years ago.

A study by Torkomian, Santos and Soares (2016) reveals that there is a growing number of students and faculty engaging in academic activities somehow related to entrepreneurship in the country. However, there are still some important challenges to overcome in this context, for instance, the majority of the work performed by the Brazilian universities' technology transfer offices is related to intellectual property and not to the transference of technology to industry.

Plonski (2016) referred to the 85th Federal Constitution Amendment, which was approved in February, 26th, 2015 and that included scientific research as a priority given its contribution to the development of Science, Technology and Innovation. The expectation at that time, was that this inclusion would be an important step for the improvement of the Triple Helix environment in Brazil. On the contrary, unfortunately, this prediction has failed and in 2019, science and technology have been facing harsh budgetary cuts which compromise the country's capabilities to produce and use innovation (Corte, 2019).

Based on this Brazilian example, some may be led to conclude that the Triple Helix approach should not be applied to study the relationship between the state, the universities and industry in developing economies. But we believe that our model of analysis, by bringing Institutional Theory into the Triple Helix approach, is a response to this criticism in itself. If "...all theories should be used in a context sensitive manner" (Whetten, 2009 p. 38), the triumph of our model is precisely making the concept of the Triple Helix sensitive to the context of emerging economies, making us aware of all the intricacies of each studied reality.

The theoretical aspect of this essay is rooted on the social construction of perspectives of reality (Berger \& Luckmann, 1966), and more specifically, on the recursive interplay between institutional pressures and institutional work, under which individuals and organizations are at the same time producers and products of the institutional environment (Bjerregaard \& Jonasson, 2014; Ferguson, 1998; Machado-da-Silva, Fonseca \& Crubellate, 2005).

In this sense, it should be recognized that our central model, demonstrated graphically through Figure 4 , is representative, at least for now, of broad empirical expectations regarding the emergence of the phenomenon of entrepreneurial universities. It is important to highlight that we consider here the institutional pillars model as a difference of explanatory rationality (Scott, 
2014). Although one would expect an overlap between the pillars of each one of the Triple Helix spheres, it is possible to predict the predominance of one pillar or another when taking into account each one of the specific spheres.

In other words, our expectation is that as the Triple Helix processes develop - in any specific case - to the formation of a stem cell space, as shown in Figure 2 - element $d$, those institutional forces and the helical spheres themselves become, recursively, cooperatives. At this more advanced stage of interactions, the helical spheres and institutional forces overlap in a balanced way, which means that the pressures cease to be external to the entrepreneurial university and become organically internalized and legitimate, that is, institutionalized, as demonstrated in the color gamut (Figure 4).

Clearly, this recursive sense points to the predominance, in our model, of a cultural-cognitive perspective, emphasizing the expectation of the emergence of university action models in search of innovation and relationship with the state and industry, or society in a broader sense, and even the relationship

\section{REFERENCES}

Agune, R., \& Carlos, J. A. (2017). Radar da inovação - O que os governos precisam enxergar. Estudos Avançados, 31(90), 143-157. http://dx.doi.org/10.1590/s010340142017.3190010

Almeida, M., Santos, D., Aragão, L., Nogueira, G., Bonifácio, A., Simões, B., \& Terra, B. (2016). Expanding the vision of entrepreneurial universities: A case study of UNIRIO in Brazil. Triple Helix, 3(1), 1-19. https://doi.org/10.1186/ s40604-016-0033-x

Arbix, G., \& Miranda, Z. (2017). Políticas de inovação em nova chave. Estudos Avançados, 31(90), 49-73. http://dx.doi. org/10.1590/s0103-40142017.3190004

Associação Fórum Nacional de Gestores de Inovação e Transferência de Tecnologia (FORTEC) (2015). Estatuto Social. Retrieved from http://fortec.org.br/wp-content/ uploads/2016/05/Estatuto-aprovado-em-151207-2.pdf

Audy, J. (2017). A inovação, o desenvolvimento e o papel da universidade. Estudos Avançados, 31(90), 75-87. http:// dx.doi.org/10.1590/s0103-40142017.3190005

AUTM (2019). The leading technology transfer resource. Retrieved from https://autm.net/AUTM/media/AboutAUTM/Documents/AUTM_Tech_Transfer_Resources_ MAY2019.pdf

Battilana, J., Leca, B., \& Boxenbaum, E. (2009). How actors change institutions: Towards a theory of institutional entrepreneurship. Academy of Management Annals, 3, 65-107. Retrieved from https://www.tandfonline.com/ doi/full/10.1080/19416520903053598?scroll=top\&ne edAccess $=$ true between the multiple inner agents of the sphere here called academy.

In the consensus space, roles, actions, objects and goals become locally legitimated, constituting part of the local system (therefore, organizational system) of beliefs and values. While they seek to meet the requirements of their own identity as actors of the university context, the participants continuously affect and are affected by a shared cultural framework. This framework, in turn, can be understood as both an outcome of the participants' daily activities performance, and as a condition for their own performance.

Finally, we believe our model of analysis allows fair comparative studies between two or more universities even if they belong to completely different institutional contexts, as it sheds light on the interplay between each of the universities and its respective institutional environment formed by the three spheres of the Triple Helix in aggregate, along with a greater emphasis on the institutional work performed by institutional entrepreneurs. Our suggestion for future research is to present comparative studies dedicated to comprehend how these institutional processes influence universities' entrepreneurial turn over time.

Berger, P. L., \& Kellner, H. (1981). Sociology reinterpreted: An essay on method and vocation. Garden City, NY: Anchor Press/Doubleday.

Berger, P., \& Luckmann, T. (1966). The social construction of reality: A treatise in the sociology of knowledge. Garden City, NY: Anchor Press/Doubleday.

Bjerregaard, T., \& Jonasson, C. (2014). Managing unstable institutional contradictions: The work of becoming. Organization Studies, 35(10), 1507-1536. https://doi. org/10.1177/0170840614530913

Boxenbaum, E.; \& Battilana, J. (2005). Importation as innovation: Transposing managerial practices across fields. Strategic Organization, 3(4), 355-383. https:// doi.org/10.1177/1476127005058996

Brew, A. (2009). Academic research in contemporary society. In M. Tight, K. H. Mok, J. Huisman, \& C. C. Morphew (Eds.). The routledge international handbook of higher education (Chap. 34, pp. 473-485.). New York: Routledge.

Capello, R., Olechnicka, A., \& Gorzelak, G. (2013). Introduction: cities, regions and universities as knowledge and innovation creators. In: R. Capello, A. Olechnicka, \& G. Gorzelak. (Eds.). Universities, cities and regions: loci for knowledge and innovation creation (Chap. Introduction, pp. 1-9). New York: Routledge.

Cohen, M., March, J. G., \& Olsen, J. P. (1972). A garbage can model of organizational choice. Administrative Science Quarterly, 17(1), 1-25. Retrieved from http://www. jstor.org/stable/2392088 
Corte orçamentário de $42 \%$ em ciência e tecnologia preocupa entidades: durante a campanha, Jair Bolsonaro disse que meta era aumentar financiamento na área. (2019, Apr. 3). Folha de São Paulo. Retrieved from https:// www 1.folha.uol.com.br/ciencia/2019/04/corteorcamentario-de-42-em-ciencia-e-tecnologia-preocupaentidades.shtml

Dias, A. A., \& Silveira Porto, G. (2013). Gestão de transferência de tecnologia na Inova Unicamp. Revista de Administração Contemporânea, 17(3), 263-284. http:// dx.doi.org/10.1590/S1415-65552013000300002

DiMaggio, P. J. (1988). Interest and agency in institutional theory. In L. G. Zucker (Ed.), Institutional patterns and organizations (pp. 3-32). Cambridge, MA: Ballinger.

DiMaggio, P. J., \& Powell, W. W. (1983). The iron cage revisited: institutional isomorphism and collective rationality in organizational fields. American Sociological Review, 48(2), 147-160. Retrieved from http:// woodypowell.com/wp-content/uploads/2018/03/ DiMaggioPowellThe-Iron-Cage-Revisited 1983.pdf

Etzkowitz, H. (2008). The triple helix: University-IndustryGovernment innovation in action. New York: Routledge.

Etzkowitz, H., \& Zhou, C. (2017). Hélice Tríplice: inovação e empreendedorismo universidade-indústria-governo. Estudos Avançados, 31(90), 23-48.: http://dx.doi. org/10.1590/s0103-40142017.3190003

Ferguson, P. P. (1998). A cultural field in the making: Gastronomy in the 19th century France. American Journal of Sociology, 104(3), 597-641. https://doi. org/10.1086/210082

Foss, L., \& Gibson, D. V. (2015a). The entrepreneurial university: Case analysis and implications. In L. Foss \& D. V. Gibson (Eds.). The entrepreneurial university: Context and institutional change (Chap. 12, pp. 249279.). New York: Routledge.

Foss, L., \& Gibson, D. V. (Eds.). (2015b) The entrepreneurial university: Context and institutional change. New York: Routledge.

Gibson, D. V., \& Foss, L. (2017). Developing the entrepreneurial university: Architecture and institutional theory. World Technopolis Review, 6(1), p. 1-15. https://doi. org/10.7165/wtr17a0809.16

Gillmor, C. S. (2004). Fred Terman at Stanford: Building a discipline, a university, and Silicon Valley. Stanford: Stanford University Press.

Goldstein, H. A. (2010). The 'entrepreneurial turn' and regional economic development mission of universities. The Annals of Regional Science, 44(1), 83-109. https://doi. org/10.1007/s00168-008-0241-z

Greenwood, R., \& Suddaby, R. (2006). Institutional entrepreneurship in mature fields: The big five accounting firms. Academy of Management Journal, 49(1), 27-48. https://doi.org/10.5465/ AMJ.2006.20785498
Gulati, R., Puranam, P., \& Tushman, M. (2012). Meta-organization design: Rethinking design in interorganizational and community contexts. Strategic Management Journal, 33(6), 571-586. Retrieved from https://dash.harvard. edu/handle/1/9932096

Havas, A. (2015). Types of knowledge and diversity of business-academia collaborations: Implications for measurement and policy. Triple Helix, 2(1), 1-26. https://doi.org/10.1186/s40604-015-0023-4

Hoffman, A. J. (1997). From heresy to dogma: An institutional history of corporate environmentalism. San Francisco: New Lexington Press.

Hofstede, G. (1991). Culture and organizations: Software of the mind. New York: McGraw-Hill.

Krause, K. L. (2009). Interpreting changing academic roles and identities in higher education. In M. Tight, K. H. Mok, J. Huisman \& C. C. Morphew (Eds.), The routledge international handbook of higher education (Chap. 30, pp. 413-425.). New York: Routledge.

Lawrence, T. B., \& Suddaby, R. (2006). Institutions and institutional work. In S. R. Clegg, C. Hardy, T. B. Lawrence, \& W. R. Nord (Eds.), Handbook of organization studies (2nd ed., pp. 215-254). London: Sage.

Leydesdorff, L., \& Park, H. W. (2014). Can synergy in triple helix relations be quantified? A review of the development of the triple helix indicator. Triple Helix, 1(4), 1-18. https://doi.org/10.1186/s40604-014-0004-z

Loise, V., \& Stevens, A. J. (2010). The Bayh-Dole act turns 30. Science Translational Medicine, 2(52), 1-5. https://doi. org/10.1126/scitranslmed.3001481

Luengo, M. J., \& Obeso, M. (2013). El efecto de la triple hélice en los resultados de innovación. Revista de Administração de Empresas, 53(4), 388-399. http:// dx.doi.org/10.1590/S0034-75902013000400006

Machado, H. P. V., Sartori, R., \& Crubellate, J. M. (2017) Institucionalização de núcleos de inovação tecnológica em instituições de ciência e tecnologia da região sul do Brasil. Revista Eletrônica de Administração, 23(3), 5-31. http://dx.doi.org/10.1590/1413-2311.177.67190

Machado-da-Silva, C. L., \& Fonseca, V.S. (1996). Competitividade organizacional: Uma tentativa de reconstrução analítica. Organizações \& Sociedade, 4(7), 97-114. http://dx.doi. org/10.1590/S1984-92301996000400004

Machado-da-Silva, C. L., Fonseca, V. S., \& Crubellate, J. M. (2005). Unlocking the institutionalization process: Insights for an institutionalizing approach. Brazilian Administration Review, 2(1), 01-20. http://dx.doi. org/10.1590/S1807-76922005000100002

Mello, C. M. de (2017). A influência das instituições no processo de construção da confiança interorganizacional. Organizações \& Sociedade, 24(81), 343-360. http:// dx.doi.org/10.1590/1984-9230818

Mello, L. E. A., \& Sepúlveda, E. S. (2017). Interação academiaindústria. Relato da experiência da Vale. Estudos Avançados, 31(90), 89-101. http://dx.doi.org/10.1590/ s0103-40142017.3190006 
Mollas-Gallart, J., Salter, A., Patel, P., Scott, A., \& Duran, X.(2002). Measuring third stream activities, report to the Russell Group universities. Brighton: SPRU.

Mowery, D. C. (2005). The Bayh-Dole act and high-technology entrepreneurship in U. S. Universities: chicken, egg, or something else? In G. D. Libecap (Ed.). University Entrepreneurship and Technology Transfer: process, design and intellectual property (Vol. 16, pp.39-68). Greenwich, CT: Jai Press/Elsevier

Pache, A. C., \& Santos, F (2010). When worlds collide: The internal dynamics of organizational responses to conflicting institutional demands. Academy of Management Review, 35(3), 455-476. https://doi. org/10.5465/amr.35.3.zok455

Padgett, J. F., \& Powell, W. W. (2012). The problem of emergence. In: J. F. Padgett; W. W. Powell (Eds.). The emergence of organizations and markets (pp. 1-29). Princeton: Princeton University Press.

Petersen, A. M., Rotolo, D., \& Leydesdorff, L. (2016). A triple helix model of medical innovation: Supply, demand, and technological capabilities in terms of Medical Subject Headings. Research Policy, 45(3), 666-681. https://doi.org/10.1016/j.respol.2015.12.004

Phillips, N., \& Tracey, P. (2007). Opportunity recognition, entrepreneurial capabilities and bricolage: Connecting institutional theory and entrepreneurship in strategic organization. Strategic Organization, 5(3), 313-320. http://doi.org/10.1177/1476127007079956

Pinto, H. (2017). Connecting the triple helix space: Actornetwork creation and institutionalisation of knowledge transfer offices. Triple Helix, 4(2), 1-23. https://doi. org/10.1186/s40604-017-0045-1

Plonski, G. A. (2017). Inovação em transformação. Estudos Avançados, 31(90), 7-21. http://dx.doi.org/10.1590/ s0103-40142017.3190002

Plonski, G. A. (2016). University technology transfer in Brazil: A comprehensive picture. In S. M. Breznitz, \& H. Etzkowitz (Eds.), University technology transfer: The globalization of academic innovation (pp. 436-441). New York: Routledge.

Popadiuk, S., Rivera, E. R., \& Bataglia, W. (2014). Heterogeneity of isomorphic pressures: Intertwining the resourcebased view and the neoinstitutional approach. Brazilian Administration Review, 11(4), 455-475. http://dx.doi. org/10.1590/1807-7692bar2014130003

Ranga, M., \& Etzkowitz, H. (2013). Triple helix systems: An analytical framework for innovation policy and practice in the knowledge society. Industry \& Higher Education, 27(3), 237-262. https://doi.org/10.5367/ ihe.2013.0165

Rodrigues, F. C. R., \& Gava, R. (2016). Capacidade de apoio à inovação dos Institutos Federais e das Universidades Federais no estado de Minas Gerais: Um estudo comparativo. Revista Eletrônica de Administração, 83(1), 26-51. http://dx.doi.org/10.1590/14132311.0282015 .5445
Rosa, R. A., \& Frega, J. R. (2017). Intervenientes do processo de transferência tecnológica em uma universidade pública. Revista de Administração Contemporânea, 21(4), 435-457. http://dx.doi.org/10.1590/19827849rac2017160097

Rossoni, L. (2016). O que é legitimidade organizacional? Organizações \& Sociedade, 23(76), 110-129. http:// dx.doi.org/10.1590/1984-9230766

Rossoni, L., Guarido, E. R., Filho, \& Coraiola, D. M. (2013). Recomendações metodológicas para a adoção da perspectiva da estruturação nos estudos organizacionais. Organizações \& Sociedade, 20(66), 523-542 http://dx.doi.org/10.1590/S198492302013000300009

Saxenian, A. (1994). Regional advantage: Culture and competition in Silicon Valley and Route 128. Cambridge, MA: Harvard University Press.

Schattschneider, E. E. (1975). The semisovereign people: A realist's view of democracy in America. Chicago: Wadsworth Thomson Learning.

Schmidt, S., Balestrin, A., Engelman, R., \& Bohnenberger, M. C. (2016). The influence of innovation environments in R\&D results. RAUSP - Revista de Administração (São Paulo), 51(4), 397-408. http://dx.doi.org/10.1016/j. rausp.2016.07.004

Schoen, A. (Coord.) (2006). Strategic management of university research activities, methodological guide. Lugano: PRIME Project 'Observatory of the European University. Retrieved from http://www.enid-europe.org/PRIME/ documents/OEU_guide.pdf

Scott, W. R. (2014). Institutions and organizations: ideas, interests and identities (4th ed). Thousand Oaks: Sage.

Scott, W. R. (2016). Institutional theory's past and future contributions to organization studies. (Interview by Juliana Marangoni Amarante). Brazilian Administration Review, 13(3), 1-6. Retrieved from http://www.anpad. org.br/periodicos/arq_pdf/b_436.pdf

Suddaby, R. (2010). Challenges for institutional theory. Journal of Management Inquiry, 19(1), 14-20. https:// doi.org/10.1177/1056492609347564

Tolbert, P. S., David, R. J., \& Sine, W. D. (2011). Studying choice and change: The intersection of institutional theory and entrepreneurship research. Organization Science, 22(5), 1332-1344. https://doi.org/10.1287/ orsc. 1100.0601

Torkomian, A. L. V., Santos, M. E. R., \& Soares, T. J. C. C. (2016). The Innovation Law, the creation of technology transfer offices and their impact on the brazilian innovation landscape. In S. M. Breznitz, \& H. Etzkowitz (Eds.), University technology transfer: The globalization of academic innovation (pp. 336-360). New York: Routledge. 
United Nations Educational, Scientific and Cultural Organization (UNESCO). (1998). Declaração mundial sobre educação superior no século XXI: Visão e ação. Retrieved from: http://www.direitoshumanos.usp. br/dh/index.php/Direito-a-Educa\%C3\%A7\%C3\%A3o/ declaracao-mundial-sobre-educacao-superior-noseculo-xxi-visao-e-acao.html.

Vorley, T. (2015). Foreword. In: L. Foss, \& D. V. Gibson (Eds.), The entrepreneurial university: Context and institutional change (Chap. Foreword, pp. xxiv-xxv). New York: Routledge.

\section{Authors}

\section{Juliana Marangoni Amarante*}

Av. Colombo, no 5790 - Bloco C23, 87020-900, Maringá, Paraná, Brazil

E-mail address: juliana.marangoni.amarante@gmail.com

(1) https://orcid.org/0000-0003-1510-6978

\section{João Marcelo Crubellate}

Av. Colombo, no 5790 - Bloco C23, 87020-900, Maringá, Paraná, Brazil

E-mail address: jmcrubellate@uem.br

(D) https://orcid.org/0000-0003-1446-8248

* Corresponding author

\section{Contributions}

$\mathbf{1}^{\text {st }}$ author: this study is resultant from her doctoral thesis. She was responsible for creating the model and writing the essay.

$2^{\text {nd }}$ author: as the doctoral advisor, he provided guidance throughout the elaboration of the study, contributing specifically with the creation of the model and reviewing the essay.
Vorley, T. \& Nelles, J. (2008). (Re)conceptualising the academy: Institutional development of and beyond the third mission. Higher Education Management and Policy, 20(3), 1-17. http://dx.doi.org/10.1787/17269822

Weick, K. E. (1976). Educational organizations as loosely coupled systems. Administrative Science Quarterly, 21(1), 1-19. https://dx.doi.org/10.2307/2391875

Whetten, D. A. (2009). An examination of the interface between context and theory applied to the study of chinese organizations. Management and Organization Review, 5(1), 29-55. https://doi.org/10.1111/j.17408784.2008.00132.x

\section{Funding}

This study was financed in part by the Coordenação de Aperfeiçoamento de Pessoal de Nível Superior - Brasil (CAPES) - Finance Code 001. It was also financed in part by the Lemann Center for Entrepreneurship and Educational Innovation in Brazil, as the 1st author received a scholarship from this institution while at Stanford University as a visiting student researcher.

\section{Conflict of Interest}

The authors have stated that there is no conflict of interest.

\section{Plagiarism Check}

The RAC maintains the practice of submitting all documents approved for publication to the plagiarism check, using specific tools, e.g.: iThenticate. 